\title{
Astrology and Science: A Precarious Relationship Part 1: Historical Review of German Astrology in the 2oth Century and Current Developments
}

\author{
Gerhard MAYer \\ Institut für Grenzgebiete der Psychologie und Psychohygiene, Freiburg i. Br./Germany \\ mayer@igpp.de
}

Submitted October 14, 2019; Accepted March 20, 2020; Published December 15, 2020

https://doi.org/10.31275/20201695

Creative Commons License CC-BY-NC

\begin{abstract}
This two-part essay illuminates the difficult relationship between astrology and science from different perspectives. While the first part provides a historical review of developments in the 2oth century in German-speaking countries, the second part (also in this issue) concerns theoretical and methodological considerations for empirical investigations of the validity of astrology. During the 2oth century, astrology in the German-speaking world was influenced by a few people who pursued a special quest for connectivity with scientific findings and models as well as a natural philosophical foundation. The astrologer Thomas Ring developed an elaborate 'astrological anthropology', the "revised astrology", which claimed to be compatible with other scientific disciplines like biology and psychology. Hans Bender, who was willing to carry out experiments in order to test astrology, became an interested counterpart to Ring. This openness to scientific scrutiny combined with the desire to replace old concepts based on magical-analogical thinking with concepts more compatible with scientific models, met with the criticism of several astrologers in the 1990s. The critics found the psychological-scientific aspiration represented as too restrictive. This led, with general sociocultural developments, to a change in the "astrology scene," which is described, among other things, on the basis of some expert interviews at the end of this first part article.
\end{abstract}

Keywords: astrology; experiment; magical thinking; revised astrology; science; Thomas Ring; psychologization of astrology 
As it is generally known, astrology was one of the recognized academic disciplines until the 17th century. Astronomy and astrology were not yet separate; nevertheless, if one could speak of a changeable history at that time, then the reasons for it lay not in challenges from scientific, but from religious concerns (Campion, 2009; Knappich \& Thiel, 1988, p. 102 ff.; Stuckrad, 2003). This changed when astrology entered a crisis in the second half of the 17th century that, although it had many causes, ultimately led to the "differentiation of branches of knowledge" (Stuckrad, 2003, p. 265) and the sustainable exclusion of astrology from the canon of sciences. Although this did not lead to the "extinction" of this "science," it was more or less pushed into the private sphere or occult underground as a serious practice. One exception was the situation in England, where public interest in astrology remained consistently high (Curry, 1989; Stuckrad, 2003, pp. 270-274). This unbroken line of tradition in England finally helped astrology to flourish again in France and Germany toward the end of the 19th century by reimporting it via theosophy.

Meanwhile, these known facts can be read in corresponding historical representations (Campion, 2008, 2009; Knappich \& Thiel, 1988; Stuckrad, 2003; Willis \& Curry, 2004, pp. 65-76). One means of adapting astrology to modern thinking was its psychologization, influenced by the Age of Enlightenment. In a way, this saved astrology through the 2oth century, comparable to the situation of Western ritual magic (cf. Hanegraaff, 2006). ${ }^{1}$ An essential instrument was depth psychology and especially the theory of archetypes by Carl Gustav Jung. In England and the USA, such a strongly psychologically dominated interpretation of astrology developed directly from the theosophical and New Age approaches as represented by the prominent astrologers Alan Leo and Dane Rudhyar (Campion, 2012, pp. 51-69). As a result, esoteric concern among these main protagonists determined the path to psychological astrology. In the German-speaking countries astrology developed differently in the 2oth century. Special efforts were made to reintegrate astrology into the academic sciences, which strongly influenced the situation until the early 1990s.

In this historical review, this development and changes since the 1990 s will first be briefly portrayed and supplemented by a status determination from an emic point of view based on statements by 
professional astrologers. Today a central point of the precarious relationship between astrology and science is mutual misunderstanding compounded by a lack of knowledge and differentiation from both astrologers and scientists. This leads to misjudgment. In the second article that follows this one, "Part 2: Considerations of Empirical Investigations on the Validity of Astrology," I will present and try to clarify these problems.

\section{ASTROLOGY IN GERMAN-SPEAKING COUNTRIES IN THE 20 ${ }^{\mathrm{TH}}$ CENTURY}

Astrology will in the coming years become the acute scientific dispute...

—Letter from Thomas Ring to Hannah Höch, dated October 4, $1927^{2}$

\section{Pluralism and the Heyday during the Weimar Period}

At the beginning of the 2oth century, especially during the Weimar period, a brief phase of ideological pluralism prevailed in Germany, allowing people to follow their interests in alternative interpretations of the world. Einstein's theory of relativity, for example, created a furor and turned understanding of the physical laws of nature upside down. ${ }^{3}$ Astrology benefited from this development as did several esoteric movements. ${ }^{4}$ After its reimport from England, several new "schools" of astrology had formed in the German-speaking area, and astrological societies and journals were established. One can speak of a flourishing period of sophisticated astrology in Germany (Howe, 1984, pp. 78-103; v. Stuckrad, 2003, pp. 321-329; Knappich \& Thiel, 1988, pp. 307-329, 350-355). The ideological pluralism could also be found in astrology: There coexisted competing approaches and concepts side by side, representing various degrees of esotericism, traditional fatalistic orientation, and also orientation toward psychological and scientific interpretations. Even Karl Brandler-Pracht (1864-1939), an astrologer strongly influenced by theosophical ideas and interests in spiritualism (Howe, 1984, pp. 81-84; Schellinger, 2009; v. Stuckrad, 2003, pp. 322$323)^{5}$, promoted a scientific and psychological approach to astrology. ${ }^{6}$ German astrologer A. M. Grimm (1892-1962), who organized the first European Astrologers' Congress in Munich in 1922, "contributed a wonderful piece of half-baked nonsense on 'Astrology and Einstein's 
Theory of Relativity"' (Howe, 1984, p. 96). Howe writes about the period of time between the two World Wars: "The German preoccupation with astrology at that time was unparalleled in any other European country or the U.S.A." (ibid., p. 7). The idea of a "psychological astrology" was first mentioned by German astrologers (ibid., p. 98) who referred to Carl Jung's analytical psychology. However, a second reference to psychology was the Charakterologie, which deals with the issue of psychological types (ibid., p. 99). Both can be seen as early approaches to personality psychology. The attempts to bring astrology and science closer together could certainly be understood in the context of an "antidisenchanting trend" (Asprem, 2014a) in parts of early 2oth-century science, that relying above all on insights from quantum physics questioned a materialistic, mechanistic, and reductionist worldview represented by "classical" science. Many researchers interpreted the new developments in science as an approximation to Natural Theology, which counteracts the "disenchantment of the world" (sensu Max Weber); among them were prominent scientists such as Nils Bohr, Werner Heisenberg, Wolfgang Pauli, Hans Driesch, William James, and William McDougall (Asprem, 2014a, 2014b).

The orientation of astrology toward psychological and scientific interpretations became a prominent feature of its further development after the Second World War. ${ }^{7}$ A number of well-known astrologers from this period could be mentioned ${ }^{8}$ but, with regard to later development, I will introduce only the names of three: the physician and astrologer Herbert Freiherr von Klöckler (1896-1950), the psychoanalyst and astrologer Fritz Riemann (1902-1979), and the artist, author, and astrologer Thomas Ring (1892-1983). These three astrologers had an extraordinary influence on postwar astrology in Germany up until the 1990s-at least as far as the specific approach mentioned above is concerned.

\section{Herbert Freiherr von Klöckler}

Herbert Freiherr von Klöckler (Figure 1) was closely oriented toward psychology and the sciences, and aimed for an empirical (statistical) investigation of astrology. He wanted to free astrology from its medieval "ballast", i.e. concepts that are difficult to integrate into a modern worldview, and create a version more compatible with modern 
times (Howe, 1984, p. 100). $\mathrm{He}$ rejected deterministic and fatalistic ideas of astrology, as well as the concept of a static and fixed character of a person. Moreover, he related astrology strongly to astronomical facts. Therefore, he refused astrological prognostic methods that refer to symbolic relationships, as is the case with the various progression methods whereby, for example and to mention one of the most common procedures, the formula "one day equals one year" is used. 9 In 1926, he published his book Astrologie als Erfahrungswissenschaft [Astrology as empirical science], in-

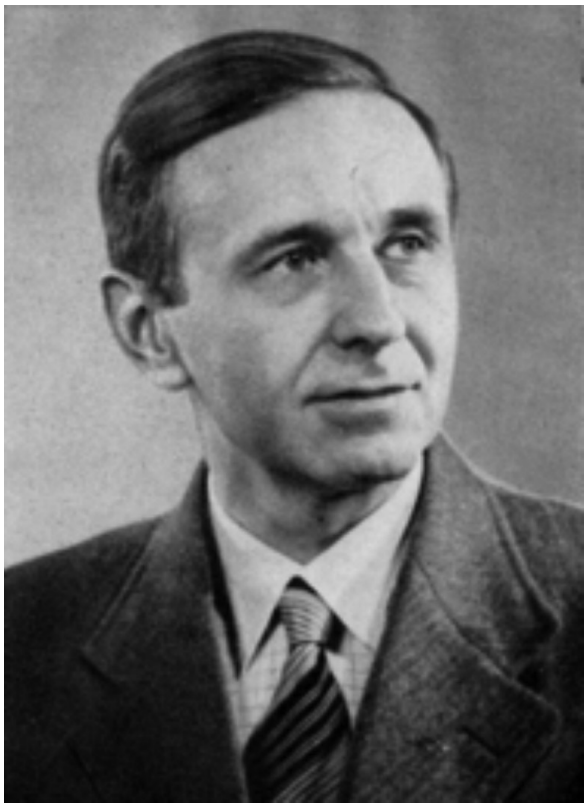

Figure 1. Herbert Freiherr von Klöckler. Source: H. Freiherr von Klöckler, Kursus der Astrologie, Band II, AstraVerlag, 1952, frontispiece. cluding an introductory note by the famous biologist Hans Driesch, and in 1929 his Kursus der Astrologie [Course of astrology], published in three volumes widely used among astrologers (Klöckler, 1991). Klöckler's emphasis on experience is mainly directed against skeptical objections that want to dismiss astrology uninspected as the result of superstitious and outdated thinking. He writes in the introduction of Astrologie als Erfahrungswissenschaft:

One may now also regard astrology, the belief in the stars, as the result of a purely intellectual or, as we would like to express ourselves today, a speculative achievement, but even then one is obliged to test this supposed speculation empirically before it is finally rejected. [...] In any case, the astrological assertion occurs everywhere and at all times with a serious claim to experience that has been had and is always possible again, and this fact compels the objective researcher to verify, reject or confirm it by means of experience. A priori, not the least can be said about the alleged facts. This is also the reason why a rejection of astrological claims cannot be justified 
by purely historical motives, as some people would like. (Klöckler, 1989 , p. 3; emphasis in the original; translation by G. M.)

However, he also turns against the "rampant charlatanism" ("grassierende Scharlatanerie") in astrology that makes it easy for the critics to dismiss it in general:

The botch-up in the field of astrology is mainly due to the fact that completely uneducated people give their clients copies and reproduced representations from textbooks based on the position of the sun. 'Better' botchers still take into account the position of the other planets on the day of birth, but in this case they also give quite stereotypical statements. (ibid., p. 368; translation by G. M.)

Klöckler advocates an open-ended empirically based approach to astrology, which sees the achievements of the "ancestors" critically, but does not reject them as superstitious or fantastic from the outset, just because some of their scientific assumptions have proven to be wrong.

\section{Fritz Riemann}

Fritz Riemann (Figure 2) was a disciple of Freiherr von Klöckler. However, he became mainly known as a psychoanalyst and founder of an "Institut für psychologische Forschung und Psychotherapie" [Institute for Psychological Research and Psychotherapy, later renamed Academy of Psychoanalysis and Psychotherapy]. He was also an honorary member of the American Academy of Psychoanalysis in New York. He wrote an influential book on anxiety, Grundformen der Angst (1961), published in 1975 as a revised and extended edition. ${ }^{10}$ Although it is written from a depth-psychology perspective, astrologically experienced readers can easily recognize that Riemann's typology of anxiety is guided by astrological concepts of the four elements, and of the planet Saturn. In his later years, he openly confessed to practicing astrology. ${ }^{11}$ In the television programme Astrologie-Tatsachen und Meinungen [Astrology-Facts and opinions], a production of a German public television broadcaster from 1958, he emphasized the usefulness of astrology in the context of psychotherapeutic work. The astrological chart helped him to unravel the overlay of disposition and environmental factors of a patient: 
For the recognition of this actual being [the being as it is before environmental influences have an effect -G. M.], astrology offers itself as a symbol in the horoscope, as it were, of how a person is thought or designed before the environment could have any influence, inhibition or distortion on him. In any case, for me the horoscope and the insight into the horoscopic connections means a protection against the danger that we, as therapists, can all be subject to, of perhaps misjudging a person, of seeing him wrong, of perhaps unconsciously pushing him in a direction of his development that does not belong to his actual nature. ${ }^{12}$

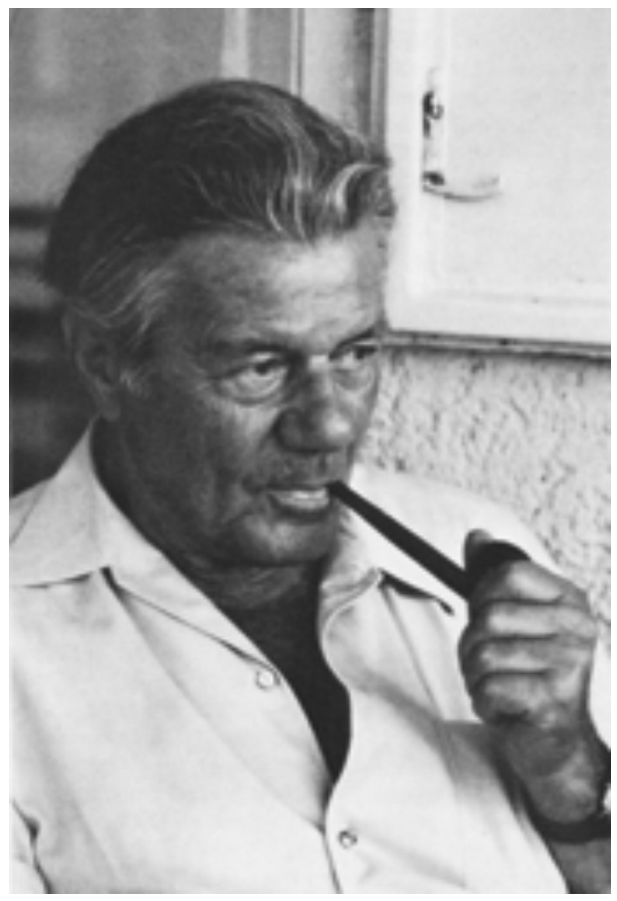

Figure 2. Fritz Riemann. Source: L. Pongratz (Ed.), Psychotherapien in Selbstdarstellungen, Verlag Hans Huber, 1973, plate after p. 352 .

In 1972, he wrote an article for the Zeitschrift für Parapsychologie und Grenzgebiete der Psychologie with the title "Über die Praxis astrologischer Beratung" [On the practice of astrological counseling] (Riemann, 1972). In the same year he gave a lecture on the occasion of the IV International Forum for Psychoanalysis in New York entitled "Psychoanalyse und Astrologie" [Psychoanalysis and astrology], in which he compared the psychoanalytic process of making conscious unconscious content ("Wo Es war, soll Ich werden" [Where id is, there shall ego be]-Freud, 1933, p. 111) with the disclosure of 'the still earlier cosmic environmental imprint" (Riemann, 1977, p. 258). In both cases, psychoanalysis and astrology, the "idea of very early imprints that are unconscious (or have become) and have fateful effects" (ibid.) forms the basic concept. Finally, in 1976, three years before his death, 
he published a book entitled Lebenshilfe Astrologie-Gedanken und Erfahrungen [Life assistance astrology-Thoughts and experiences]. With this book he wanted to situate serious astrology, ${ }^{13}$ which explicitly distinguishes itself from magical and fatalistic ideas, as valuable help in a professional therapeutic context.

\section{Thomas Ring}

The most important person with regard to so-called revised astrology was the artist, author, and astrologer Thomas Ring (Figure 3). Rather skeptical at first, he developed a complex form of astrological anthropology, according to the title of his main work in four volumes, Astrologische Menschenkunde. He coined the term "Revidierte Astrologie" (revised astrology) (Ring, 1956, 1959, 1969, 1972, 1973) in order to distinguish it from the mechanistic and fatalistic "classical astrology." Ring referred heavily to a psychological approach to the conception of man. Philosophical anthropology as well as scientific findings in general also appealed to him.

\section{Thomas Ring's Astrological Anthropology}

The main question of Ring's approach concerns the relation of the human being to his Welthintergrund [background of his world, or cosmic embedding] (Ring, 1975, p. 9). According to his model, the stars, or heavenly bodies, do not affect human beings directly by way of a physical force. The connection of the "above" with the "below" is

solely the movement, physically the celestial mechanics, biologically and psychologically the life movement. Thus, the problem is reduced to whether, and to what extent, the changeable, volatile, and convertible can be implemented into the uniformly recurring. This is conceivable as the rhythmic integration of vital processes into the regular recurrence of configurations ["Konstellationen"] of the solar system. (Ring, 1975, p. 13; emphasis in original; translation by G. M.)

During pregnancy, the developing fetus becomes increasingly attuned to the astronomic environment and its rhythmic structure including the earth. Therefore, one could see the human organism as a macroscopically embedded system oscillating with an individual 
constant basic rhythm adjusted to cosmic norms. The (future) mother chooses instinctively, and unconsciously, the "appropriate" point in time for conception. The delivery is the termination of the pregnancy period and, therewith, of the adjustment period of a new human organism before it becomes an autonomously functioning organism. Thus, the chart can be regarded as kind of a "discharge paper" (ibid., p. 24), displaying the result of the individual attunement period to cosmic oscillation patterns. The horoscope itself has to be allegorically interpreted.

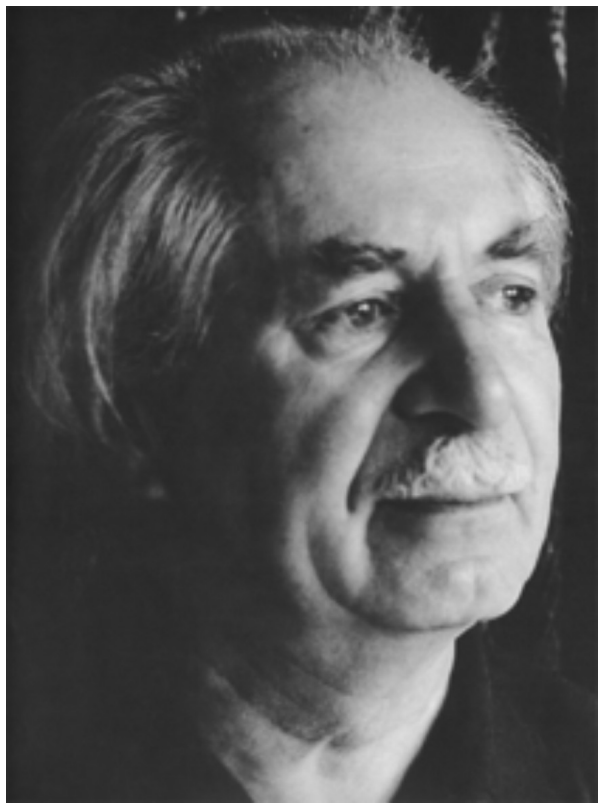

Figure 3. Thomas Ring. Source: T. Ring, Lebenszeugnisse, Thomas-RingStiftung, 1982, p. 10.

The link between external, cosmological structures, and the internal constitution of a human being is not causal but correlative, a symbolic analogy of the Bildekräfte (forming powers) or Wesenskräfte (elemental forces) in human beings themselves (ibid., pp. 14-15). The Bildekräfte are the basis of all organisms, i.e. every living organism is subject to these forces (or laws) (cf. Francé, 1921). They are perceived in the form of mythological figures or dream images. The Wesenskräfte are structurally ordered at the time of birth forming an individual pattern reflected by the cosmic constellations at this point in time.

In Ring's model of astrological anthropology, astrology adopts a position between biology and psychology. Accordingly, human individual behavior is determined by the genotype (genetic makeup), cosmotype ("cosmic" makeup), and phenotype, resulting from genotype, cosmotype, and environmental factors. Table 1, based on his astrological texts, ${ }^{14}$ juxtaposes these three aspects.

Ring can be characterized as a very sophisticated and analytical astrologer. He distinguishes accurately, and explicitly, between the 
levels of astrological signs, planets, and houses, and he does not equate, for example, "sun position in Aquarius," "Uranus in conjunction with the sun," "ascendant in Aquarius," and "Uranus in conjunction with ascendant," ${ }^{15}$ as often can be found with other astrologers and astrological textbooks of 2oth-century astrology. Although there is a kind of family likeness, to use a term by Wittgenstein, the mentioned

TABLE 1

Genotype, Cosmotype, and Phenotype According to Ring's Model

\begin{tabular}{|c|c|c|}
\hline Genotype & Cosmotype & Phenotype \\
\hline genetic constitution & "transformer" & environment \\
\hline \multirow[t]{6}{*}{ isolated heredity traits } & hereditary structure & $\begin{array}{l}\text { developed traits, habits, } \\
\text { interests, behavior }\end{array}$ \\
\hline & "essence" & "existence" \\
\hline & structural constraint & self-determining factor \\
\hline & principle & concretum \\
\hline & developmental tendencies & developments / events \\
\hline & astrology & psychotherapy \\
\hline
\end{tabular}

constellations concern different things. According to such an analytical approach, the planet answers the "which"-question (which vital force?), whereas the sign answers the "how"-question (how, or with which dynamic, is it likely to manifest?), and the house answers the "where"-question (where, i.e. in which sphere of life, is it likely to come particularly to the foreground?). Such an analytical distinction presents a complex astrological interpretation that is logically more consistent than the many simplified astrological approaches of the last century, especially against the background of his quest for a scientifically compatible model of astrology.

Like Klöckler, Ring also defended astrology against three sides: against outdated and uncritically adopted fatalistic assumptions of classical astrology, against uncritical skeptical rejections of astrology out of arrogance and prejudice, and against uncritically simplified 
astrological beliefs by naïve occult believers. The latter is reflected in his book title Astrologie ohne Aberglauben [Astrology without superstition] (1972). He compares the situation of astrology with that of parapsychology, which is also hindered and threatened by ideologized and unscientific skepticism and uncritical paranormal believers. $\mathrm{He}$ considered it a problem that astrology "returned in the wake of the occult" leading to "a misleading ideological packaging of traditional ideas" (1972, p. 110; translation by

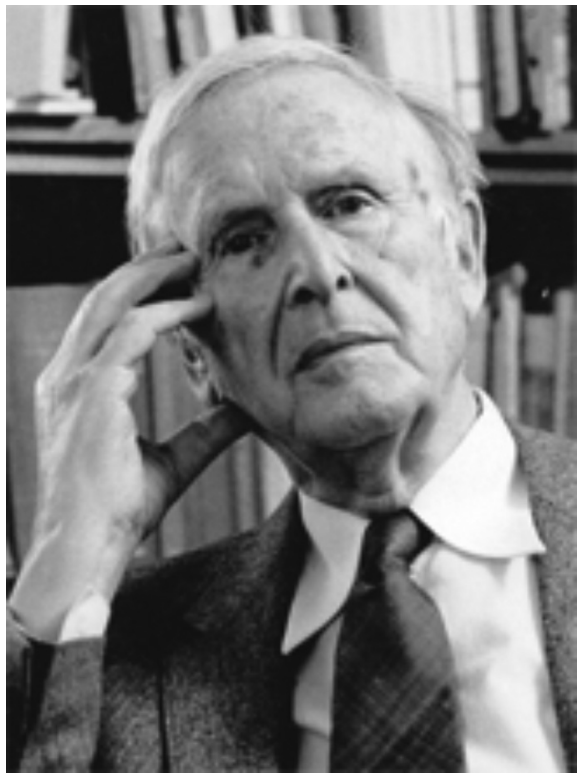

Figure 4. Hans Bender. Photo credit: Archive of the IGPP.

G. M.). Furthermore, "the impression was created that one was not at the beginning of new research, but before the sacred, finally formulated" (ibid.).

Ring's closeness to parapsychological research was established with his collaboration with the psychologist and founder of the Institut für Grenzgebiete der Psychologie und Psychohygiene (IGPP), Hans Bender (1907-1991) (Figure 4), who became the leading figure in parapsychological research from the 1940 os until his death in 1991 (see below, and at the beginning of the second article, following this one). The approach of the revised astrology by Thomas Ring is in line with the approach of parapsychological research in its distance from primitive occultism. The above-mentioned television program Astrologie-Tatsachen und Meinungen (1958) provides an excellent picture of the problematic situation. Astrologer Ring, psychotherapist Riemann, and parapsychologist Bender try to demonstrate the value of a modern, non-simplifying, astrological practice, while philosopher and sociologist Theodor W. Adorno (1903-1969) speaks about astrology being nothing more than a question of belief and simple (secondary) superstition. ${ }^{16}$ 
This short description of the main characteristics of Ring's approach to astrology may illustrate his committed attempt to reconnect with academic disciplines. It may also make understandable the attractiveness it had for many scientists and psychologists. Another important appeal was Ring's fascinating personality. Not by chance, he impressed the well-known German physicist and philosopher Carl Friedrich von Weizsäcker, who then concerned himself with chart-reading for a certain period of time. ${ }^{17}$ Additionally, Hans Bender (Figure 4) assisted Ring by appointing him director of his "Grenzwissenschaftliche Institut" at Strasbourg University (Hausmann, 2006, p. 109f., 2013; Skiebe, 1998, p. 165). Ring had been transferred to a punishment unit, a "death squad," in 1943 by the Nazi regime during World War $11 .{ }^{18}$ The collaboration between Bender and Ring continued after the war. ${ }^{19}$ Scientific investigations into astrological issues remained a research topic at the IGPP until Hans Bender's death.

\section{THE POSTWAR PERIOD UNTIL THE 19905}

During the postwar period, an emphasis on psychological approaches and an aim for scientific-empirical evaluation dominated German astrology. This emphasis in astrology brought on by pre-war developments in the field re-emerged following the Nazi regime persecutions of astrologers, and a period of disruption to the astrological scene in Germany (Howe, 1984; Schubert-Weller, 1988a, 1988b). Both psychologization and the scientific approach were propelled by the collaboration of the psychologist and parapsychologist, Hans Bender, with Thomas Ring and other astrologers, including Walter Böer (1914-2007) in particular. Bender, who carried out a first astrological experiment with Karl Ernst Kraff (1900-1945) as early as 1937 at Bonn University (Howe, 1984, p. 154) succeeded with tests with Ring in 194445 at Strasbourg University (Howe, 1967, p. 244, 1995), ${ }^{20}$ conducted a scientific study in the 1950 (1952-1954) on the "Investigation of unaccredited practices of interpretation and counseling"-a paraphrase of astrological counseling practice-that was partly funded by the DFG (German Research Foundation). ${ }^{21}$ In several test series, astrologers were asked to prepare written astrological reports, which were then checked for consistency by psychological experts, or the astrologers were shown psychological reports to which they were asked to assign the horoscopes 
belonging to them. In sum, the astrologers- 178 were involved in total-did not notably perform; although a significant correlation could be found between astrological and psychological assessments. Still, a small set of astrologers, including Böer and Ring (Figure 5), stood out significantly from the group (Werthmann, 1971). ${ }^{22}$ Böer had been chosen as an astrological expert in several other experiments and had cooperated with IGPP research projects up until the late 1980s (e.g., Böer et al., 1986). ${ }^{23}$

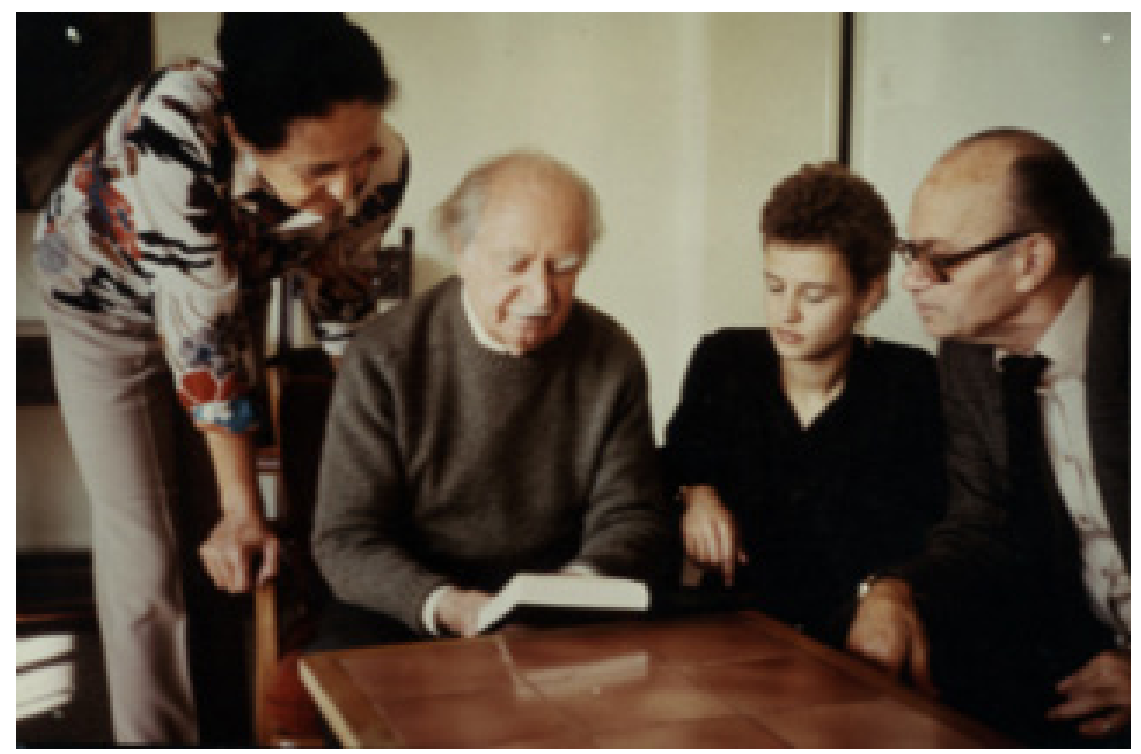

Figure 5. Astrologers Thomas Ring (2nd from left) and Walter Böer (right) with two IGPP staff members at IGPP in the early 1980s. Photo credit: IGPP Archive.

Carl Jung, who was also in contact with Bender, carried out a comprehensive study on astrological synastry in the early 1950 s with the horoscopes of 483 married couples, and an extensive statistical analysis (Jung, 1957/1958).24 In 1968, psychologist Hans-Volker Werthmann finished a dissertation on a test of the validity of astrological horoscope interpretations in comparison with other psychodiagnostic methods (Werthmann, 1968, 1971, 1972, 1973). The German Zeitschrift für Parapsychologie und Grenzgebiete der Psychologie [ZPGP-Journal of Parapsychology and Frontier Areas of Psychology], founded by Bender in 1957, became a main platform for publishing scientific articles on 
astrology. Even the French researcher Michel Gauquelin, who had been conducting important statistical investigations into astrology since the early 1950 s and had established his approach of Neo-Astrology (e.g., Gauquelin, 1991), corresponded with Bender and the IGPP, and published several of his articles in that scientific journal. In total, 56 scientific papers on astrological issues were published in the ZPGP between 1957 and 1996. They deal with various (often exploratory) experiments as well as replications and variations of Gauquelin's research (Ertel, 1986, 1992a, 1992b, 1993, 1995; Müller, 1986; Müller \& Menzer, 1993). In summary, the experiments at the IGPP provided mixed results-interesting enough to maintain this kind of research for several decades, but too unclear to convince skeptics.

Furthermore, esoteric or technically oriented, fatalistic astrological approaches (e.g., the so-called "Hamburger Schule" [Hamburg School]) also could be found in this period in the German-speaking world, but they remained largely overshadowed, or did not have much of an impact on the further development of astrology, at least in Germany in the second half of the 2oth century. ${ }^{25}$

Another culmination of this postwar development in Germany occurred in the 1980s, when a young psychologist and former staff member of the IGPP, Peter Niehenke, became president of the "Deutscher Astrologenverband" DAV [German Astrological Association] for a period of ten years (1981-1991). He became an important link between the strongly scientific approaches to astrology, represented by the research initiated and promoted by Bender and the IGPP, and the astrological community lacking a scientific background. In this respect, he can be described as a great popularizer of psychological and scientific astrology. His main objectives were to give astrology a new and modern face, and to release it from the sphere of backroom meetings in station restaurants (personal conversation). During this time, Niehenke wrote his dissertation Kritische Astrologie [Critical astrology] (1987) on a comprehensive questionnaire-based study of the correlation between horoscope factors and psychological variables (personality traits)-the first dissertation on an astrological subject in Germany based on empirical data of this kind. His psychological approach was in line, to a certain degree, with similar developments in the USA and Great Britain propelled by astrologers such as Liz 
Greene, Dane Rudhyar, Stephen Arroyo, and others. During his term of presidency, the number of members of the association, which had been about 100 in 1950, increased up to nearly 1,000. He initiated annual conventions as well as founding training centers and a research center associated with the DAV. In order to maintain a high standard of quality, such training centers, called "Ausbildungszentren des Deutschen Astrologenverbandes", have to meet several criteria to obtain approval by the DAV. ${ }^{26}$

In 1983, a Grundsatzpapier astrologischer Vereinigungen [statement of principles of astrological associations] was published that was signed by the presidents of the four biggest German astrological associations (cf. Wunder \& Voltmer, 2007, pp. 12-14). In 1984, the president of the Schweizer Astrologen-Bund, Bruno Huber, also added his signature. This policy paper bore the hallmarks of Niehenke (ibid., pp. 14-16), who was largely influenced by the astrological anthropology of Thomas Ring as well as the cleared-out and empirically oriented astrology of Freiherr von Klöckler and the depth psychological approach of Riemann. It was aimed at a clear demarcation of seriously practiced, psychologically oriented astrology from yellow-press astrology, but also from strongly deterministic approaches. ${ }^{27}$ Niehenke pursued two goals with the policy paper: He wanted to enable a concerted action against the strong pressure from skeptics with the statement of principles paper containing the lowest common denominator of the different astrologer associations ("I needed this paper as "weapon"”; ibid., p. 16). He also wanted to facilitate expert-policy steps toward a professionalization of astrological counseling activities. These goals were regarded by the participating associations as important enough that they were willing to swallow some rather bitter pills for them. ${ }^{28}$

\section{THE SITUATION FROM THE 1990S ONWARD}

Several developments occurred during the 1990s that had, and still have, great impact on the astrological scene and practice. These developments are largely global in nature. For this reason, the points in the following list are not specific to Germany, but apply to almost all modern societies. But they are important for understanding the further development of the astrological scene in the German-speaking world —in contrast to the situation before the 1990s. The characteristic 
path for more than half of a century thus was increasingly left:

C Esoteric beliefs and practices formerly mainly part of the subculture enter mainstream society. Almost every magazine acquired its own esoteric corner presenting not only sun sign astrology columns but much more extensive articles on yoga, shamanic healing, etc.-practices that are connected with the labels "New Age" and "esoteric scene" (for Germany, cf. Mayer 2003, 2004).

$\square$ The growing use of commercial broadcast as well as the commercialization of the Internet produced increasing competitive pressure on 'classic' media (public service television, print media, etc.), and provided alternative platforms for astrologers.

$\square$ The Internet and television programs such as Astro TV created a new form of astrological practice between simple sun sign horoscopes in magazines and sophisticated astrological counseling based on serious training. These new services, which can be assigned to the entertainment industry (cf. Campion, 2012, pp. 132-33), encompass a broad audience and might strongly influence the public image of astrology. As the audience of these programs does not usually differentiate between astrology, reading the cards, and scrying, the critics often do not.

$\square$ The rapid spread of computer technology facilitated the work of astrologers enormously (Wunder, 2005, p. 292). This made it possible for untrained people to print their astrological charts and to describe them rudimentarily with interpretation text modules. For trained astrologers, the work with new astrological elements has become much easier.

$\square$ In the astrological scene, people who advocated for approaches other than psychological, such as esoteric astrology, classical astrology, or horary astrology, succeeded in reorienting them as equivalent to the revised psychological astrology (see the expert interviews below).

$\square$ One of the foundations for this development was an increasing interest from historians in the Western astrological tradition as part of Western esoteric traditions. For example, Project 
Hindsight, a translation project founded as part of this tradition, in 1993 operated for the retrieval of historic astrological texts. Also important was the founding of the Sophia Centre for the Study of Cosmology in Culture at Bath Spa University in 2002 (now at The University of Wales Trinity Saint David, Lampeter), where an MA degree in Cultural Astronomy and Astrology (York, 2003) can be obtained.

Due to the near complete failure of attempts to provide scientific evidence of astrology during the second half of the $20^{\text {th }}$ century, pursuits in a scientifically guided approach to astrology decreased strongly. ${ }^{29}$

The presidents of the DAV who succeeded Peter Niehenke addressed different main topics. However, two themes can be identified: (1) an emphasis on astrology as a profession, and (2) attempts to accept multiple astrological approaches or schools, such as the "Hamburger Schule", which affected the exclusiveness of the scientifically and the psychologically oriented attitudes. The first resulted in periodic hearings on professional policies, and, after many attempts, one training center succeeded in that its astrological training was approved by job centers and pension funds. ${ }^{30}$ The second resulted in a reformulation of the statement of principles between 2011 and 2013 that has now been adapted to cover a larger range of astrological approaches, for example horary astrology. It is significantly shorter, and less precise, than the first version..$^{31}$ Its most important adjustment concerns the issues of forecasting and how astrology might be scientifically evaluated. Thus, not included in the new version are the statements "Astrological forecasting is based on the interpretation of the changes in the astronomic structure caused by the course of the celestial bodies" (part of the former thesis 2), and "The existence of the mentioned correlation is a reality that is basically accessible to empirical-scientific evaluation (.. .)" (part of the former thesis 3 ).

\section{A Decline of Interest in Astrology?}

The debate about what should be included in the spectrum of serious astrology peaked. According to Holger Faß, the editor of the astrology journal Meridian, this was one of the reasons for a significant decrease 
in the number of DAV members from about 1,100 in the late 1990 s to currently about $600 . .^{32}$ It is difficult to assess whether the decline in membership indicates a general decline in interest in astrology, which would be a social trend. Further data from other sources seem at first glance to indicate similar results: According to the statement of the director of a prominent, and international, provider of computergenerated astrological horoscopes (Astrodienst), astrology reached its highest point in the early 1990 s and is now in decline. Requests from Germany and Switzerland have dropped by $25 \%$ to $35 \%$ since that peak. ${ }^{33}$ The same applies to providers of astrological training courses. The interest of younger people in astrology looks much lower than three decades ago. ${ }^{34}$ Not to mention the number of subscriptions to the largest German astrology magazine Meridian has declined from 3,000 at its highest count to about 2,300 today; 35 and the main publisher of astrology books in Germany notes that bookstore owners with their own corner for astrological books during the 1970s to the 1990s do not have such books on offer anymore. Direct sales have now completely disappeared. ${ }^{36}$ The demand for ephemeris books, a basic tool for astrologers, has largely decreased. However, the available computer software makes printed ephemerides largely superfluous. And online booksellers such as Amazon have a significant impact on direct sales. In any event, print media are generally in decline. Further indicators are also difficult to interpret. "Google Trends," for example, show a steady decline in the popularity of the term "Astrologie" in relation to other terms such as "Tarot" and "Kartenlegen" [cartomancy, divination with cards] since 2004, but the data lacks absolute values of the number of searches. ${ }^{37}$

One considerable problem with the assessment of genuine interest in astrological counseling is that information technology has significantly changed the way people search for information. To make a point, a few years ago the administration office of the DAV had received many requests for lists of addresses of serious astrologers. The requests have now almost disappeared because most information is immediately available on the Internet. This easy access makes it difficult to distinguish between serious searches for information and surfing through websites out of pure curiosity. Furthermore, the decline of consultation requests could partly be a result of astrological 
services being offered on the Internet (e.g., computerized horoscope analyses and interpretations for free). ${ }^{38}$ Thus, all of the assessments and statements have to be treated with caution. ${ }^{39}$

\section{Assessments by Astrologers and Other Experts in the Field}

From 2010 to 2012, the German astrological magazine Meridian published the opinions of several prominent German astrologers regarding the current situation and the future of astrology..$^{40}$ These impressions, combined with information from 11 expert interviews I conducted in 2016,41 form the basis of the following depiction of the current situation in the astrological scene. The depiction has the main purpose of sharpening the picture of the situation before 1990 by way of contrast and comparison. The interviews were conducted with the following key question: What has changed in the astrology scene over the last decades? The changes should refer to different areas: the situation in astrological training centers, astrological practice, and the needs of the clientele. The aim of the comparison determined the selection of the interview partners. They had to be involved in the field long enough to take positions (e.g., in astrological associations) that provide a good overview and insight into the astrological scene. Some of them are still following the psychological approach described above that characterized the situation before 1990; others are more open to the new developments, and even significantly involved in them. ${ }^{42}$ One interviewed person, Alois Treindl, founded Astrodienst, a company that offers computer-generated horoscope interpretation; Reinhardt Stiehle runs the main publishing houses for astrological books in Germany (Chiron and astronova), and Martin Garms is responsible for the production of the astrological magazine Meridian. This sheds light on the situation from various aspects. The heterogenity of the interviewed persons produced a significant variety of assessments. However, a few main features become evident, which I will summarize in the following.

Firstly, a new ideological pluralism has become established for different approaches to astrology, comparable to the first quarter of the 2oth century. The spectrum reaches from the view of astrology as an absolutely esoteric way of wisdom that has nothing to do with science, and the social everyday reality, right up to a constructivist interpretation of astrology as a useful fiction. According to this approach, 
astrology is basically alterable and independent of an ontological reality of astronomical facts. It is seen as a human-made tool for organizing one's life (cf. Weidner, 2002). This pluralism is not only found among different astrologers but also within individual astrological practices. Several long-term astrologers with training in psychological astrology now combine it occasionally with elements of horary astrology. They try to integrate elements of traditional astrology into their practice in a non-dogmatic manner.

Secondly, a professional turning toward astrology can be found in two respects: Astrology has by now become an important topic of historiography and historical studies, together with astrologers adopting a utilitarian approach to astrology aiming for social acceptance of astrology as a consulting service comparable with psychological counseling. For this purpose, they create elaborate curricula and examinations for ambitious training of astrologers, and engage in issues of professional policy in order to distinguish their approach from the purely commercial offerings.

Finally, astrology that is understood as a profession from which one can make a living, tends to pursue a connection to psychology and have a certain interest in a scientific foundation; while astrology that is understood as an esoteric path to wisdom teachings is not strongly directed toward social acceptance, but sees itself in a particular role, and finds it easier to come to terms with a marginal position in society.

The statements of the astrologers vary considerably when it comes to the aims and needs of the clientele. This is not surprising because the individual approaches and appearances of astrologers fluctuate with their personalities and separate preferences. Thus, astrologers' specific clientele and assessments cannot be generalized. For instance, some say that a boost in young people looking for astrological advice took place, and the search for serious astrological counseling has increased during recent years, as has the general acceptance of astrology as a valuable tool. Others notice that for most clients, a deeper interest in astrology and astrological counseling does not begin until about the age of 40 years. Comparatively, many astrologers report that an increasing number of inquiries are from people looking for short and direct answers to definite yes-no questions. Others emphasize that there is little change, if any. The main areas of substantive help sought 
from astrology professionals remain the same: love, profession, family. Some astrologers assess their clients as better-informed than in the past. More versed in the limits of interpretation of horoscopes, they are more cautious with predictive issues. Nevertheless, a general observation is that the use of astrology as a tool for psychological introspection and self-awareness is increasingly being replaced by the desire for concrete answers to questions of everyday problems. Only minimal attention is given to the philosophical background. A pragmatic attitude seems to dominate with the clientele, which is also reflected, for example, in contracts for astrological coaching of management teams of a major company, as one astrologer reported. Some astrologers report that this is caused by a pronounced consumer attitude of many clients. One considers it possible that the psychological approach to astrology is exhausted due to the vagueness of astrological statements, as well as the dense introduction of new astrological methods and elements leading to a large arbitrariness of interpretive approaches and "schools." He says that, at some point, almost every astrologer has developed his or her own little method of interpreting horoscope charts. This appears somewhat exaggerated, of course, but a glance into astrological magazines displays a pronounced tendency to experiment with new astrological elements or ways of interpretation-maybe propelled by the wish to stand out from colleagues.

Concerning astrological education offered in DAV training centers, reports show a significant demand for seminars and courses during recent years. "The subscribers want to get comprehensive course material, want to see something professional for their money," said a long-term provider of astrological training courses; and another stated that almost no beginners are subscribing to the training courses, but advanced autodidacts who are using information available on the Internet. From another point of view, those with positions skeptical of astrology are often unknown to the subscribers, maybe due to the highly selective gathering of information from respective communities on the Internet. ${ }^{43}$ Training centers prepare well-educated astrologers year by year to make money; yet, the most they can do is supplement their main earnings. Few can act on their intention of making a living from astrology. Concurrently, business is going quite well for established and well-known astrologers.

A considerable change is also observed in technical practice: 
Decreasing numbers of people find their way into the consulting rooms of astrologers. Telephone and video conference counseling has greatly increased. Most of the interviewed astrologers make a definite distinction between the clientele of serious astrologers and those responding to services offered on the Internet and commercial broadcasts. Such services address a form of personality structure that is in search of a more authoritarian style of counseling than is generally the case with people who consult an astrologer. Thus, the overlap between the two clienteles seems to be very small. However, concentrating on the astrologers, the transitions between these two fields are more fluid than some astrologers might wish. Some of them had worked, and are still working, for Internet portals such as Questico, mainly due to economic pressure. The clientele of commercial providers is mildly unsatisfactory for reputable astrologers because such people do not want to deal with their problems in depth, but only require concrete and short ad hoc answers to questions such as, "What will happen where and when?" Conversely, these commercial forms introduce astrology to a wider audience and sometimes bring new clients to astrologers. As one astrologer put it: "people are not as stupid as one might think. Critical individuals will quickly distance themselves from such cheesy interpretations and services. Questico improved the public awareness of astrology, which ultimately led to a significant growth in well-informed autodidacts."

In keeping with the above statements it is important to note that the interviewed people are prominent astrologers who have acquired a certain reputation by writing books and articles for astrological magazines. They are not representative of astrologers in the aggregate. Beginners may have different experiences with their clienteles.

\section{SUMMARIZING CONSIDERATIONS OF HISTORICAL DEVELOPMENT}

In summary, it can be said that the development of astrology in Germany took a specific route during the 2oth century insofar as it was characterized by an aim for compatibility with scientific findings and models as well as a natural philosophical foundation. Such efforts were not limited to the German-speaking world, of course, but the 
unusual concentration and prioritization might be characteristic for the situation in Germany, and are due to the fruitful encounter of unusually committed and potent minds. In France, too, attempts were made to investigate astrology with statistical methods in the early $20^{\text {th }}$ century, by Paul Choisnard (e.g., in 1908, under his pseudonym Paul Flambart), and the groundbreaking research by Michel Gauquelin and Françoise Schneider-Gauquelin, which started in the 1950s, is well-known beyond scientifically oriented astrologers. Although the results obtained by the Gauquelins were significant and generated a scientific earthquakeone special case shows the prominent psychologists Hans Eysenck and David Nias changed their minds about astrology by starting to review the literature and perform experiments (Eysenck \& Nias, 1982, p. x) -the Gauquelins' neo-astrological approach is a specific case and differs substantially from the other scientific approaches followed mainly by German astrologers and scientists. ${ }^{44}$ In contrast to the view of, for example, Willis and Curry (2004, pp. 65-76), who differentiate between "scientific astrology" and "psychological astrology," they tried to combine scientific approaches to psychology and astrology (by means of differential and personality psychology, etc.).

The foremost influential proponent was Thomas Ring, followed by Peter Niehenke, who expanded astrology with elements of systems theory. This led to several scientific experiments considering the correlation between astronomical structures and events and personality structures on earth, as well as the capacity of astrologers to match tasks and consulting situations. On the basis thereof, it resulted in a strongly, psychologically dominated interpretation of astrology, which, however, in the sense of Ring's astrological anthropology, was by no means limited to the psychological aspects. With regard to the latter, this was in line with what was happening in Great Britain and the USA. Regarding the latter, it differed from developments in Great Britain and the USA, where, as Campion (2012, pp. 51-69) points out, psychologization emerged directly from the theosophical and New Age approaches of Alan Leo and Dane Rudhyar and, thereby, the movement to psychological astrology was basically fueled by a different, particularly esoteric, aim. The astrologer Robert Hand complained that 2oth-century astrology lacks a theoretical foundation and a clear, elaborate language (Hand, 2005). 45 This is not true with regard to German astrology; unfortunately, 
the important works of several German astrologers of the 2oth century were not translated into English, and consequently were not received in the English-speaking world. ${ }^{46}$ The acceptance of an extensive range of astrological approaches in German astrological associations during the last decades, including a critical attitude toward the possibility of scientific evaluation of astrology, have largely put an end to the special situation in the German-speaking area. It seems that the rich treasury of works by the above-mentioned German astrologers such as von Klöckler and Thomas Ring is no longer an indispensable component of an astrologer's training in Germany, although the books are still, and easily, available (at low prices). ${ }^{47}$ For many, reading the material by Ring is judged to be too complex, and the wording outdated. "Ring does not gain acceptance anymore. Nobody wants to read such a complex work," as the main publisher of astrology books in Germany, Reinhardt Stiehle, put it..$^{8}$

The rise of a more deterministic, if not fatalistic, astrology certainly results from a tendency toward a pragmatically oriented approach in this practice. Questions about the "why" and "how," with the aim at a deeper (philosophical) understanding, have dropped into the background. The characteristic astrologer has changed during recent years due to the fact that it is no longer necessary to calculate the charts by hand. The Internet provides astrological calculations in conjunction with interpretation programs. Several astrologers orient their practices to the requests of a clientele that wants quick, short, and concrete ad hoc answers, and do so using methods of "classical" and horary astrology. The former president of the Astrological Lodge of London, Bernard Eccles, gave a lecture in 2015 painting a very culturally pessimistic picture of the future development of astrology which he sees as exposed to a great danger of simplification, a prognostic "black-andwhite" astrology, delivering concrete yes-no answers via mobile phone applications without the need for thorough consideration (Eccles, 2015). 49 Eccles is by no means to be agreed with on all of his arguments and above all his conclusion. With his reference to new, network mediabased forms of knowledge acquisition, coupled with the habituation of pervasive and direct access to information, he may have grasped one reason (out of several) for the aforementioned change in dealing with astrology in the sense of concrete problem-solving strategies. 
In the second part, the article following this, the focus is on considerations of empirical investigations on the validity of astrology. A definitive clarification and useful concepts and practices are crucial issues for the assessment of empirical studies of astrology. A distinction will be made between the above-below theorem as the traditional basic assumption of astrology and possible psi phenomena that can occur in astrological counseling practice. Specific methodological problems of these approaches are addressed.

\section{ACKNOWLEDGMENTS}

I sincerely acknowledge and appreciate the valuable comments and suggestions of the anonymous reviewers, which helped to improve the manuscript.

\section{NOTES}

1 Through psychologization it was possible to turn to "magical" thinking and acting in a symbolic way and to relate them to the inner psychic dynamic and not to the external world subject to the laws of physics. Thus, it did not blatantly conflict with the modern scientific worldview, and the criticism of superstitious behavior leads nowhere.

2 Quoted from Skiebe (1988, p. 148), translated by G. M. [author of this paper]. Hannah Höch (1898-1978) was a German artist. The astrologer and artist Thomas Ring (1892-1983) met her in 1914 in Berlin. They both were part of the artistic Dada movement (Skiebe, 1988, p. 54f.).

3 See Asprem (2014a, 2014b) for a comprehensive presentation of the intellectual history of science, religion, and "the occult" during this period.

4 Ellic Howe's Astrology \& The Third Reich (1984) gives a thorough overview of the development of astrology in Germany during the first half of the $20^{\text {th }}$ century. See Treitel's study (2004) on fin-de-siècle German occultism, as well as the later studies by Wolffram (2009) and Sommer (2013) on the formation of German psychical research. Henderson (2016) emphasizes the interest of Theosophists in contemporary science at this time with the example of the monthly German spiritualist periodical Die Uebersinnliche Welt. 
5 See also http://wiki.astro.com/astrowiki/de/Karl_Brandler-Pracht

6 In a handbook on astrological diagnosis and prognosis he wrote the following caveat: "Warning! The rules for interpretation presented here are based on old traditions and are therefore not yet sufficiently psychologically founded. The psychological foundation of these traditional sets of rules will be the task of future research" (BrandlerPracht, 1938, p. 173, translation by G. M.).

7 Of course, it is problematic to speak of astrology in singular form and thus of "its development," since there are very different forms of practice which cannot be lumped together. This is discussed in more detail in the article following this one.

8 The Swiss astrologer Karl Ernst Krafft (1900-1945), for example, conducted extensive statistical investigations of birth charts (see Howe, 1984, for a profound presentation of Krafft's biography and political role during the Third Reich). Elsbeth Ebertin (1880-1944) and her son Reinhold Ebertin (1901-1988) established their own astrological "school," named "cosmobiology" (or the Ebertin school). Alfred Witte (1878-1941) developed a new method of calculating and interpreting charts which was called the "Hamburger Schule," and known as "Uranian Astrology" or the "Uranian System" in English-speaking countries.

9 Klöckler named these methods as "fictitious methods" because they do not refer to the relation between actual planetary motion and biographical development in a synchronous course of time, but rather relate different time scales to each other by means of the application of certain conversion keys. He called these direction keys "imperfect mathematical aids," to which "the ancients," due to the lack of reliable ephemeris, used to determine future transits as aids to prognosis (Klöckler, 1989, p. 153).

${ }^{10}$ An English translation was published in 2009, entitled Anxiety: Using depth psychology to find a balance in your life.

${ }^{11}$ Riemann, however, had never concealed his interest in astrology. By 1936 he had published a small volume Die Astrologie. Ein Lehrgang in Versen [Astrology. A course in verse]. 
${ }^{12}$ Astrologie-Tatsachen und Meinungen, 1958 (at 44:55), translated by G. $M$. This television program is produced by the Süddeutscher Rundfunk Stuttgart and broadcast on December 12, 1958. It also introduces Thomas Ring, who interprets a horoscope as a demonstration of his astrological work. As a critic of astrology, Theodor W. Adorno has his say at length (see below).

${ }^{13}$ In general, the term "serious astrology" is used to distinguish astrological practice, which is based on comprehensive training and thorough knowledge of the astrological symbol system, from a superficial and oversimplified application, such as that found in the sun sign astrology of newspaper horoscopes.

${ }^{14}$ Several works could be referenced because Ring developed these concepts early on in his astrology material. Two volumes are mentioned in particular: the 1975 book Existenz und Wesen in kosmologischer Sicht [Existence and essence in a cosmological view], and Astrologie ohne Aberglauben [Astrology without superstition] from 1972, particularly, the chapter "Astrologie im heutigen Weltbild" [Astrology in the present conception of the world]. Ring gives corresponding terms for all three areas only in the first two lines. In the remaining lines he only distinguishes cosmotype from phenotype.

${ }^{15}$ In classical astrology, the signs of the zodiac were each attributed a planet as a so-called "ruler." The ruler of Aquarius is Uranus. Before its discovery it was Saturn, which then became the "second ruler."

${ }^{16}$ The subtitle of Adorno's famous analysis of astrology columns in The Los Angeles Times is "A Study in Secondary Superstition" (Adorno, 1957). In the above-mentioned television programme AstrologieMeinungen und Tatsachen from 1958 Adorno broadly follows the argumentation of this paper. What provokes him most is the claim of astrologers to pursue science or at least something close to it. Thus he states:

So if astrology really came across as what I think it is, a kind of traditional superstition, I would have as little objection toward it as I have to any wandering gypsies or old women who tell fortunes from coffee grounds. So it is precisely the claim of respectability that is being made here, and the claim that this has something to 
do with serious and controllable science, that seems to me, at least in the sense of a theory of science, to be utterly untenable. (Astrologie-Tatsachen und Meinungen, 1958, 05:04; translated by G. M.)

${ }^{17}$ In an interview in the television documentary Thomas Ring-Ein Fernsehportrait zum 90. Geburtstag [Thomas Ring-A television portrait for his goth birthday], produced by Manfred Voltmer in 1982, he expressed his opinion on this and called him a wise man.

${ }^{18}$ As a politically left-wing artist and intellectual, Ring became involved in the struggle against the rise of National Socialism and thus came into its field of vision. Later he secretly conspired with the resistance against the Nazi regime (Skiebe, 1988, p. 156). However, there was also an interest on the part of important individuals from the leadership of the Nazi government in "cosmobiology" and thus in Ring as an astrologer, who had already distinguished himself in this field with his publications. However, Ring did not enter into any cooperation (ibid., pp. 135-165).

${ }_{19}$ Bender's esteem for Ring's work was also reflected in writing the preface to Ring's volume Astrologische Menschenkunde (1956).

${ }_{20}$ IGPP archive signature 10/5 "Straßburg: Astrologischer Zuordnungsversuch 1944."

${ }^{21}$ The documents concerning this investigation can be found in the IGPP archive (signature: E/20 "DFG-Jahresbericht 1953. 'Untersuchung wissenschaftlich nicht anerkannter Deutungs- und Beratungspraktiken", 40/3: "Untersuchung wissenschaftlich nicht anerkannter Deutungs- und Beratungspraktiken: Jahresbericht 1953"). See also Bender and Timm (1967). However, it is hardly surprising that astrology skeptics such as Ludwig Reiners quickly stepped forward in order to disavow the project (see letter to the editor by Bender, 1953).

${ }^{22}$ The other members of the group of the five best performers were Ernst von Xylander, Fritz Riemann, and Willy Probst (letter from Bender to Böer of July 17, 1954; IGPP archive, E/21: Böer, Walter, 1952-1955). A reanalysis of the data of this study was made by Timm \& Köberl (1986) in order to correct statistical flaws of the first evaluation; 
nevertheless, they found a correlation on a $1 \%$ level of significance between astrological and psychological assessments.

${ }^{23} \mathrm{He}$ worked full-time at IGPP for a certain period of time during 19631964 (Howe, 1967, p. 244, 1995).

${ }^{24}$ Cf. Jung and Main, 1997, pp. 109-118, for an English translation. Jung was intensively concerned with astrology as a symbolic system and practice (Buck, 2018). His assessment varied during his lifetime. In a letter to Aniela Jaffé dated September 8, 1951, he wrote: "I have to rework my chapter on astrology. There, a significant change will occur (...). Astrology is not a mantic method but seems to be based on proton radiation (coming from the sun). I still have to conduct a statistical experiment, to be on the safe side" (Jung, 1980, pp. 230-231, translation by G. M.). However, after getting meaningful, and in certain respects significant, yet inconsistent results with his experiment, he interpreted them as the consequence of synchronicity, not of a causal correlation: "From a rational point of view, such an experiment is completely worthless, because the more often it is replicated the more likely it will have an unsuccessful outcome" (Jung, 1957/1958, p. 90, translation by G. M.). See also Mayer (2019).

${ }^{25}$ Another school with an independent approach that had achieved a relatively high level of recognition is the "Münchner Rhythmenlehre" developed by Wolfgang Döbereiner (1928-2014) in the 1950s. From another, more political point of view, a supplementary story of German postwar astrology could be written. On the one hand, it would be dominated by the struggle against critics such as Ludwig Reiners, who made a case against astrology with his 1951 book Steht es in den Sternen? [Is it written in the stars?]; and on the other hand it would be characterized by the suppression of fatal misconduct of many astrologers and their approaches to the Nazi regime as well as the creation of legends with regard to persecutions by the Nazis (Howe, 1984; Schubert-Weller, 1987a, 1987b, 1988a, 1988b).

${ }^{26}$ Currently, the website of the DAV lists 16 training centers. Five centers provide correspondence courses or webminars (http://www.astrologenverband.de/ausbildung/dav-ausbildungszentren). 
${ }^{27}$ A concise presentation of Niehenke's approach to astrology can be found in his book Astrologie. Eine Einführung [Astrology. An introduction] published in 1994 by the renowned publishing house Reclam. A discussion of policy by several German astrologers can be found in a special issue of the Zeitschrift für Anomalistik 7 (2007), pp. 9-79.

${ }^{28}$ In retrospect, Niehenke expressed himself as follows:

The fact that it was relatively easy for me to reach a consensus on central questions of astrological self-understanding among four astrological professional associations with very different orientations at that time was certainly also due to this 'external pressure,' which was created by the feeling of being slandered or discredited, or at least misunderstood. It was the more or less unconscious focus on this aspect, the unspoken consensus among us initiators, that it should be an answer to this situation that made consensus possible. So what we all know as 'political wisdom' also proved true with us: An external opponent unites. (Wunder \& Voltmer, 2007, p. 77)

${ }^{29}$ As one of the peer reviewers of this paper rightly pointed out, this is certainly not the only reason. It also has to do with which persons are able to actively carry out such research. Gauquelin's death left a large gap in the research landscape, since very few researchers are so intensively dedicated to this field. After the death of Gauquelin, for instance, access to birth data has become much more restricted due to data protection.

${ }^{30}$ Telephone conversation with Helen Fritsch on June 9, 2016. See also https://www.astrologenverband.de/verband/preisverleihunggoldener-jupiter. Since recognition must be applied for again and again at short intervals and this procedure is a considerable financial burden, this training center did not renew its approval after a few years (telephone conversation with Valeska Haker, secretary of Helen Fritsch, on February 20, 2020). However, the goal of the DAV becoming a member of the "Bundesverband der Freien Berufe e.V." [Federation of German Independent Professionals] was not achieved. This would have meant that astrology would become a fully officially recognized profession. Besides formal criteria-the association must have at least 1,000 members-there were content concerns. Skeptics 
also raised objections (telephone conversation with Klemens Ludwig, chairman of the DAV, on February 7, 2020).

${ }^{31}$ https://www.astrologenverband.de/verband/dav-thesenpapier

${ }^{32}$ Telephone conversation on May 23, 2016. Comparative figures for the membership development of the Swiss Astrological Association $(\mathrm{SAB})$, involved in the design of the thesis paper, show that this could indeed have been an important factor. Since its foundation in 1983, the number of members has risen steadily from 16 at that time to 234 as of September 2019 (e-mail from Markus Eicher, board member and vice-president of SAB, September 12, 2019).

33 Telephone conversation with Alois Treindl of May 31, 2016.

34 Telephone conversation with Raphael Gil Brand (May 30, 2016) and Martin Garms (May 6, 2016).

35 Telephone conversation with Martin Garms, producer of Meridian, of May 6, 2016.

${ }^{36}$ Telephone conversation with Reinhardt Stiehle (May 20, 2016).

37 https://www.google.de/trends/explore?hl=de\#q=Spirituell,+Lebensb eratung, + Astrologie, + Kartenlegen,+ Tarot\&geo=DE\&cmpt=q\&tz=Etc $/$ GMT-2\&tz=Etc/GMT-2

${ }^{38}$ Information by telephone from Dominique Tomaszewski of the administrative office of the DAV, on 7 June 7, 2016.

39 See also Campion on this point. I absolutely agree with his statement: "(...) there is no sure way to measure any increase or decline in interest" (2012, p. 205).

${ }^{40}$ The Meridian series with the title "Die Zukunft der Astrologie" [The future of astrology] started with issue 2/2010 and ended with 2/2012, with a gap in issue 6/2011. It consists of 12 one-page interviews in total. Meridian publishes in six issues per year.

${ }^{41}$ I would particularly like to thank the following people (in alphabetical order) with whom I had very interesting conversations about the current situation of astrology: Rafael Gil Brand, Franziska Engel, Holger Faß, Helen Fritsch, Martin Garms, Monika Heer, Klemens Ludwig, 
Reinhardt Stiehle, Dominique Tomaszewski, Alois Treindl, and Thomas Weyer-Eberling.

${ }^{42}$ Rafael Gil Brand, for instance, was one of the leading forces of the reformulation of the statement of principles of astrological associations between 2011 and 2013 (see above). He wrote the Lehrbuch der klassischen Astrologie [Textbook of classical astrology] (Gil Brand, 2000) and encourages the practical use of the old techniques which were considered obsolete with the approach of the revised astrology by Klöckler, Ring, and Niehenke.

${ }^{43}$ The so-called filter bubble theory (Pariser, 2017), according to which Internet search engine algorithms offer search results personalized according to (assumed) preferences calculated from various variables (location, websites visited, etc.), should not be sufficient to explain this. A more important reason might be that public controversies about serious astrology are much rarer: "Society has become accustomed to astrology - not in the sense of public recognition, but as one of the countless 'madnesses' that exist in modern societies, and as one of the relatively harmless ones," says Edgar Wunder in his statement on the Grundsatzpapier astrologischer Vereinigungen (Wunder \& Voltmer, 2007, p. 69).

${ }^{44}$ Cf. Ertel and Irving (1996), and Ertel (2011, 2015) for an overview of the research concerning the Gauquelin approach.

${ }^{45}$ McRitchie (2006) made similar comments. He then tried to put together elements of an astrological theory himself. His five basic principles of astrology were: (1) "correlativity" (microcosm and macrocosm correspond to each other), (2) "nativity" (every being, thing, or event has a moment of birth), (3) "co-evolution" (microcosm and macrocosm develop synchronously and in cycles), (4) "correlation" (the connections between cosmos and earthly events are not causal but correlative in nature), and (5) "co-relevance" (there is a functional coherence between microcosmic and macrocosmic events that can be interpreted as a symbolic language). This corresponds in broad outlines to the approach of psychological astrology as it was represented in the first version of the above-mentioned "Grundsatzpapier astrologischer Vereinigungen." 
${ }^{46}$ Ellic Howe wrote in 1984:

Unfortunately for English-speaking readers the most helpful books on this area are all by German authors. See Dr. H. A. Strauss, Psychologie und astrologische Symbolik, (. . .) written by a Jungian psychologist; Thomas Ring, Astrologische Menschenkunde (. . .); H. von Kloeckler, Grundlagen für die astrologische Deutung, (...) [Kloeckler is Klöckler; the book mentioned is volume 2 of the Kursus der Astrologie in three volumes-G. M.]. These books reflect an intellectual level unknown in British or American astrological writing. (Howe, 1984: 16, footnote 1)

${ }^{47}$ Due to the huge effort and generosity of Alois Treindl, founder of the "Astrodienst Zürich" and the Internet portal www.astro.com, the volumes Astrologische Menschenkunde by Thomas Ring can be downloaded for free: https://www.astro.com/astrologie/in_ring_g.htm

${ }^{48}$ Telephone interview May 20, 2016.

49 "Judgement without Consideration" was the title of his talk.

\section{REFERENCES}

Adorno, T.W. (1957). The stars down to Earth: The Los Angeles Times astrology column: A study in secondary superstition. Jahrbuch für Amerikastudien, 2, $19-88$.

Asprem, E. (2014a). Die blinden Flecken der Entzauberung der Welt: Naturwissenschaft, Parapsychologie und 'natürliche Theologie' im frühen 20. Jahrhundert. Zeitschrift für Anomalistik, 14, 141-158.

Asprem, E. (2014b). The problem of disenchantment: Scientific naturalism and esoteric discourse, 1900-1939. Brill.

Bender, H. (1953, March 11). Horoskope auf dem Prüfstand. Deutsche Zeitung und Wirtschaftszeitung, (20).

Bender, H., \& Timm, U. (1967). Ergebnisse einer Umfrage unter Astrologen. Zeitschrift für Parapsychologie und Grenzgebiete der Psychologie, 10, 115-130.

Böer, W., Niehenke, P., \& Timm, U. (1986). Lassen sich "Unfäller" astrologisch diagnostizieren? Ein exploratorisches Experiment. Zeitschrift für Parapsychologie und Grenzgebiete der Psychologie, 28, 56-65.

Brandler-Pracht, K. (1938). Astrologische Kollektion Band 3: Die astrologische Diagnose und Prognose. Görlitz: Regulus.

Buck, S. (2018). Hiding in plain sight: Jung, astrology, and the psychology of the unconscious. Journal of Analytical Psychology, 63(2), 207-227. 
https://10.1111/1468-5922.12394

Campion, N. (2008). A history of Western astrology. Vol. 1. The dawn of astrology: A cultural history of Western astrology. Continuum.

Campion, N. (2009). A history of Western astrology. Vol. 2. The medieval and modern worlds. Continuum.

Campion, N. (2012). Astrology and popular religion in the modern West: Prophecy, cosmology and the New Age Movement. Ashgate.

Curry, P. (1989). Prophecy and power: Astrology in early modern England. Princeton University Press.

Eccles, B. (2015). 21st century astrology: Judgement without consideration. Sophia Centre, 28.11.2015. http://www.cosmocritic.com/pdfs/Eccles_Bernard_ Judgement_Consideration.pdf

Ertel, S. (1986). Wissenschaftliche Qualität und progressive Dynamik im GauquelinParadigma. Zeitschrift für Parapsychologie und Grenzgebiete der Psychologie, 28, 104-135.

Ertel, S. (1992a). Ist der Gauquelin-Effekt zu erklären?-Eine Stellungnahme zu Arno Müllers Deutung der planetarischen Effekte. Zeitschrift für Parapsychologie und Grenzgebiete der Psychologie, 34, 80-87.

Ertel, S. (1992b). Ist der Mondeffekt bei Gauquelins Schriftstellern zweifelhaft? Zeitschrift für Parapsychologie und Grenzgebiete der Psychologie, 34, 225-231.

Ertel, S. (1993). Planetarische Eminenzeffekte: Verwirrende und entwirrende Befunde. Zeitschrift für Parapsychologie und Grenzgebiete der Psychologie, 35, 90-104.

Ertel, S. (1995). Die Stärke des Gauquelin-Planeteneffekts: Arno Müllers Bilanz korrekturbedürftig. Zeitschrift für Parapsychologie und Grenzgebiete der Psychologie, 37, 3-27.

Ertel, S. (2011). Rückblick (1955-2005) auf die durch Michel Gauquelin entfachte Forschung. In U. Voltmer \& R. Stiehle (Eds.), Astrologie und Wissenschaft (pp. 280-323). Chiron.

Ertel, S. (2015). Astrologie auf dem Prüfstand der Statistik. In G. Mayer, M. Schetsche, I. Schmied-Knittel \& D. Vaitl (Eds.), An den Grenzen der Erkenntnis: Handbuch der wissenschaftlichen Anomalistik (pp. 315-331). Schattauer.

Ertel, S., \& Irving, K. (1996). The tenacious Mars effect. Urania Trust.

Eysenck, H. J., \& Nias, D. (1982). Astrology: Science or superstition? M. T. Smith.

Francé, R. H. (1921). Bios: Die Gesetze der Welt (2 vol.). Hanfstaengl.

Freud, S. (1933). Neue Folge der Vorlesungen zur Einführung in die Psychoanalyse. Internationaler Psychoanalytischer Verlag.

https://archive.org/stream/Freud_1933_Neue_Folge_k\#page/n5/mode/2up

Gauquelin, M. (1991). Neo-astrology: A Copernican revolution. Arkana.

Gil Brand, R. (2000). Lehrbuch der klassischen Astrologie. Chiron.

Hand, R. (2005). Towards a post-modern astrology. British Astrological Association. 
http://www.astro.com/astrologie/in_postmodern_g.htm

Hanegraaff, W. J. (2006). Magic V: 18th-2oth century. In W. J. Hanegraaff (Ed.), Dictionary of Gnosis and Western esotericism (pp. 738-744). Brill.

Hausmann, F.-R. (2006). Hans Bender (1907-1991) und das "Institut für Psychologie und Klinische Psychologie" an der Reichsuniversität Straßburg 1941-1944. Ergon.

Hausmann, F.-R. (2013). Wissenschaftslenkung an der Reichsuniversität Straßburg: Ernst Anrich, Hans Bender und das "Grenzwissenschaftliche Institut". In K. Krimm (Hrsg.), NS-Kulturpolitik und Gesellschaft am Oberrhein 1940-1945 (S. 131-143). Thorbecke.

Henderson, L. (2016). The forgotten meta-realities of modernism: Die Uebersinnliche Welt and the international cultures of science and occultism. Glass Bead Journal (Site o: Castalia_the Game of Ends and Means).

Howe, E. (1967). Urania's children: The strange world of the astrologers. Kimber.

Howe, E. (1984). Astrology and the Third Reich. (Rev. and exp. ed.). Aquarian.

Howe, E. (1995). Uranias Kinder: Die seltsame Welt der Astrologen und das Dritte Reich. Beltz Athenäum.

Jung, C. G. (1980). Briefe II. 1946-1955. Unter Mitarbeit von Herausgegeben von Aniela Jaffé in Zusammenarbeit mit Gerhard Adler (2nd ed.). Walter.

Jung, C. G. (1957/1958). Ein astrologisches Experiment. Zeitschrift für Parapsychologie und Grenzgebiete der Psychologie, 1, 81-92.

Jung, C. G., \& Main, R. (1997). Jung on synchronicity and the paranormal: Key readings. Routledge.

Klöckler, H. v. (1989). Astrologie als Erfahrungswissenschaft. Diederichs.

Klöckler, H. v. (1991). Kursus der Astrologie. Bauer.

Knappich, W., \& Thiel, B. (1988). Geschichte der Astrologie (2nd, enlarged ed.). Vittorio Klostermann.

Mayer, G. (2003). Über Grenzen schreiben. Presseberichterstattung zu Themen aus dem Bereich der Anomalistik und der Grenzgebiete der Psychologie in den Printmedien Spiegel, Bild und Bild am Sonntag. Zeitschrift Für Anomalistik, 3(1), 8-46.

Mayer, G. (2004). Phantome-Wunder-Sensationen. Das Übernatürliche als Thema der Presseberichterstattung. Gesellschaft für Anomalistik.

Mayer, G. (2019). Editorial: Zum Kern der Sache-Carl Gustav Jung, Synchronizität und das Ringen mit empirischen Daten [To the heart of the matter-Carl Gustav Jung, synchronicity, and the struggle with empirical data]. Zeitschrift für Anomalistik, 19, 284-299. DOI: 10.23793/zfa.2019.284

McRitchie, K. (2006). Astrology and social sciences: Looking inside the black box of astrological theory. Correlation, 24 (1), 5-20.

Müller, A. (1986). Läßt sich der Gauquelin-Effekt bestätigen? Untersuchungsergebnisse mit einer Stichprobe von 1288 hervorragenden Ärzten. Zeit- 
schrift für Parapsychologie und Grenzgebiete der Psychologie, 28, 87-103.

Müller, A., \& Menzer, G. (1993). 1145 Angehörige deutscher Dynastien [1145 members of German dynasties]. (Astro-Forschungs-Daten, Bd. 4). A. P. Müller.

Niehenke, P. (1987). Kritische Astrologie. Aurum.

Niehenke, P. (1994). Astrologie: Eine Einführung. Reclam.

Pariser, E. (2017). Filter Bubble: Wie wir im Internet entmündigt werden. Hanser.

Reiners, L. (1951). Steht es in den Sternen? Paul List.

Riemann, F. (1936). Die Astrologie: Ein Lehrgang in Versen. Astra.

Riemann, F. (1972). Über die Praxis astrologischer Beratung. Zeitschrift für Parapsychologie und Grenzgebiete der Psychologie, 14, 207-221.

Riemann, F. (1975). Grundformen der Angst: Eine tiefenpsychologische Studie (1oth rev. and enlarged ed.). Reinhardt.

Riemann, F. (1976). Lebenshilfe Astrologie: Gedanken u. Erfahrungen. Pfeiffer.

Riemann, F. (1977). Psychonanalyse und Astrologie. Paper presented at the IV. Internationalen Forums für Psychoanalyse in New York, September 28-October 2, 1972. In G. Chrzanowski, A. Heigl-Evers, H. V. Brazil \& W. Schwidder (Eds.), Das Irrationale in der Psychoanalyse: Theoretische und klinische Aspekte [The irrational in psychoanalysis: Theoretical and clinical aspects] (pp. 257-267). Verlag für Medizinische Psychologie.

Riemann, F. (2009). Anxiety: Using depth psychology to find balance in your life. E. Reinhardt.

Ring, T. (1956). Astrologische Menschenkunde, Band 1: Kräfte und Kräftebeziehungen (2nd ed.). Bauer.

Ring, T. (1959). Astrologische Menschenkunde, Band 2: Ausdruck und Richtung der Kräjte (2. ed.). Bauer.

Ring, T. (1969). Astrologische Menschenkunde, Band 3: Kombinationslehre. Bauer.

Ring, T. (1972). Astrologie ohne Aberglauben. Econ Verlag.

Ring, T. (1973). Astrologische Menschenkunde, Band 4: Das lebende Modell. Bauer.

Ring, T. (1975). Existenz und Wesen in kosmologische Sicht. Aurum.

Schellinger, U. (2009). Geburtsstunde eines Sterndeuters: Der Astrologe und Okkultist Karl Brandler-Pracht (1864-1939) in seiner Ortenauer Zeit. Geroldsecker Land, 51, 92-105.

Schubert-Weller, C. (1987a). Politische Astrologie im Deutschland der 2oer und 3oer Jahre. Teil 1. Meridian (5), 23-27.

Schubert-Weller, C. (1987b). Politische Astrologie im Deutschland der 2oer und 3oer Jahre. Erste Fortsetzung und Schluß. Meridian (6), 15-21.

Schubert-Weller, C. (1988a). Verdrängte Geschichte. Legendenbildung der bundesdeutschen Astrologie nach dem Zweiten Weltkrieg. Teil 1. Meridian (4), 12-16.

Schubert-Weller, C. (1988b). Verdrängte Geschichte. Legendenbildung der bundesdeutschen Astrologie nach dem Zweiten Weltkrieg. Fortsetzung und Schluß. Meridian (5), 19-22. 
Skiebe, I. (1988). Thomas Ring-Ein Maler aus dem Umkreis des "Sturm": Leben, stilkritische Analyse und Werkverzeichnis. Bautz.

Sommer, A. (2013). Normalizing the Supernormal: The Formation of the "Gesellschaft für Psychologische Forschung" ("Society for Psychological Research"), C. 1886-1890. Journal of the History of the Behavioral Sciences, 49(1), 18-44. http://onlinelibrary.wiley.com/doi/10.1002/jhbs.21577/pdf

Stuckrad, K. v. (2003). Geschichte der Astrologie: Von den Anfängen bis zur Gegenwart. Beck.

Timm, U., \& Köberl, T. (1986). Re-Analyse einer Validitätsuntersuchung an 178 Astrologen. Zeitschrift für Parapsychologie und Grenzgebiete der Psychologie, 28, 33-55.

Treitel, C. (2004). A science for the soul: Occultism and the genesis of the German Modern. Johns Hopkins University Press.

Weidner, C. A. (2002). Astrologie-eine nützliche Fiktion. Zeitschrift für Anomalistik, 2, 197-204.

Werthmann, H.-V. (1968). Zur psychologischen Prüfung wissenschaftlich nicht anerkannter psychodiagnostischer Deutungspraktiken (dissertation). AlbertLudwigs-Universität Freiburg.

Werthmann, H.-V. (1971). Astrologie und Psychologie-Eine vergleichende experimentelle Studie. Teil I: Versuchsplanung-Und Durchführung. Zeitschrift für Parapsychologie und Grenzgebiete der Psychologie, 13, 176-191.

Werthmann, H.-V. (1972). Astrologie und Psychologie-Eine vergleichende experimentelle Studie. Teil II: Falldarstellungen. Zeitschrift für Parapsychologie und Grenzgebiete der Psychologie, 14, 155-176.

Werthmann, H.-V. (1973). Astrologie und Psychologie-Eine vergleichende experimentelle Studie. Teil III: Ergebnisse. Zeitschrift für Parapsychologie und Grenzgebiete der Psychologie, 15, 36-52.

Willis, R., \& Curry, P. (2004). Astrology, science and culture. Berg.

Wolffram, H. (2009). The stepchildren of science: Psychical research and parapsychology in Germany, c. 1870-1939. Rodopi.

Wunder, E. (2005). Religion in der postkonfessionellen Gesellschaft: Ein Beitrag zur sozialwissenschaftlichen Theorieentwicklung in der Religionsgeographie. Steiner.

Wunder, E., \& Voltmer, U. (2007). Ein Grundkonsens zur Astrologie? Kritische Kommentare zum "Grundsatzpapier astrologischer Vereinigungen". Zeitschrift für Anomalistik, 7, 9-79.

York, M. (2003). Contemporary academic study of astrology. In J. R. Lewis (Ed.), The astrology book: The encyclopedia of heavenly influences (pp. 170-179). Visible Ink Press. 